
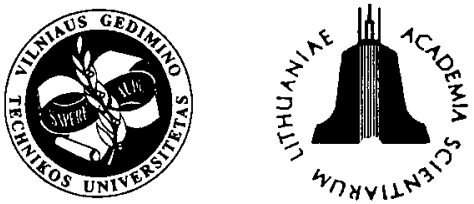

JOURNAL OF CIVIL ENGINEERING AND MANAGEMENT

http:/www.vtu.lt/english/editions

2003. Vol IX, No $1,76-81$

\title{
THE EFFECT OF THE PROCESSING WAY OF TECHNOGENIC RAW MATERIALS ON THE PROPERTIES OF GYPSUM BINDING MATERIALS
}

\author{
Violeta Leškevičienè, Dalia Nizevičienè, Zenonas Valančius \\ Dept of Silicate Technology, Kaunas Technological University, Radvilenu pl. 19, Kaunas, Lithuania \\ E-mail: zenonas.valancius@ctf.ktu.lt
}

Received 14 Apr 2001; accepted 15 Dec 2002

\begin{abstract}
Since natural gypseous raw materials are not available in Lithuania, the production of gypseous binding materials is feasible only from different process waste. In the work the results of investigations conducted on a gypseous binding material are presented, which is produced from dehydrate and semihydrate calcium sulphate (phosphogypsum) formed in JSC "Lifosa" and from gypsum forms of waste obtained in JSC "Jiesia". The processing of dehydrate phosphogypsum into gypseous binding materials has been thoroughly investigated and the created technologies have been tested in several enterprises. In 1998 in JSC "Lifosa" dehydrate technology was changed over semihydrate technology. In the work the ways of producing gypseous binding material or gypsum products are presented, which meet the requirements of the standards being in effect. For the above ways of production Lithuanian patent LT 4699 B, 200009 25 has been obtained. In JSC "Jiesia" several tons of gypsiferous waste are produced daily. The investigation results enable us to infer that it is feasible to obtain rather qualitative $b$ and a semi-hydrate gypsum from gypseous waste without additional processing and with comparatively insignificant energy consumption.
\end{abstract}

Keywords: dehydrate calcium sulphate, phosphogypsum, binding materials, gypsum, semihydrate calcium sulphate, $\alpha$-semihydrate gypsum.

\section{Introduction}

Lithuania has practically no natural gypsum (dih ydrate calcium sulphate) resources and the anhydrite beds lay deep in the ground. Therefore, production wastes could be used as a raw material for producing gypsum binding materials.

The major part of the waste is formed by JSC "Lifosa" from the phosphatic fertilizer production called phosphogypsum (previously dihydrate, currently - semihydrated calcium sulphate). When producing one ton of ortho-phosphorus acid, about 4 tons of the mentioned waste is obtained during the technological process. It is transported to the waste mountains, which are rapidly growing up every year and at present constitute about 15 million tons. Acidic admixtures present in phosphogypsum contaminate the environment. The problem of their utilization remains unsolved, although a number of scientists have already investigated the possibility of using them for producing gypsum binding materials. Literature presents many scientific works how to obtain a gypsum binding material from dihydrate phosphogypsum $[1,2]$. A range of technologies of this area has been prepared and implemented in production by the Institute of Architecture and Civil Engineering conducted by Dr S. Stonys [3-7]. In 1997, JSC "Lifosa" has changed the production technology of phosphorus acid, pursuant to which a semi-hydrate phosphogypsum - not the dihydrate - forms as a by-product. Its properties and application for production of gypsum binding products is poorly investigated. One of the main tasks for solution of phosphogypsum application is identification of admixtures and their neutralization [8-10].

Another source of gypsum waste is the worn-out gypsum forms from the fine ceramics joint-stock company (FCJSC) "Jiesia", which are used for production of porcelain and fine ceramics articles made by moulding. This factory produces up to several tons of waste every day.

Despite the possessed actual raw materials, currently no gypsum binding materials are produced in Lithuania, although gypsum and its products are successfully imported and have a great demand.

The aim of this work is to generalise the long-term research of abstraction of gypsum binding materials from dihydrate phosphogypsum and to present the scientific research results of application of current local waste semi hydrate phosphogypsum and the worn-out gypsum forms from FCJSC "Jiesia" to obtain the above mentioned materials. 


\section{Materials and methods of investigations}

\subsection{Materials}

During production of the extraction ortho-phosphorus acid at JSC "Lifosa", when resolving the apatite by a concentrated sulphuric acid in accordance with the reaction (1), phosphogypsum waste forms, in which modification of calcium sulphate depends on a range of technological parameters and on the concentration of phosphorus acid in a pulp.

$$
\begin{gathered}
\mathrm{Ca}_{5}\left(\mathrm{PO}_{4}\right)_{3} \mathrm{~F}+5 \mathrm{H}_{2} \mathrm{SO}_{4}+\mathrm{nH}_{2} \mathrm{O}= \\
3 \mathrm{H}_{3} \mathrm{PO}_{4}+5 \mathrm{CaSO}_{4} \times \mathrm{nH}_{2} \mathrm{O}+\mathrm{HF}+\mathrm{Q} .
\end{gathered}
$$

Dihydrate phosphogypsum $\left(\mathrm{CaSO}_{4} \times 2 \mathrm{H}_{2} \mathrm{O}\right)$ forms at $75-82{ }^{\circ} \mathrm{C}$ temperature by reacting the apatite with a sulphuric acid. The chemical composition (calculated for a dry product), \%: $\mathrm{CaO}-31-32, \mathrm{SO}_{3}-44-45, \mathrm{SiO}_{2}-$ $0,3-0,4, \mathrm{R}_{2} \mathrm{O}_{3}-0,5-0,9, \mathrm{Na}_{2} \mathrm{O}-0,24-0,32, \mathrm{~K}_{2} \mathrm{O}-0,04$ $0,08, \mathrm{P}_{2} \mathrm{O}_{5}$ common (c.) $-0,9 \mathrm{l}-1,50, \mathrm{P}_{2} \mathrm{O}_{5}$ water soluble (w.s.) - 0,30-0,96, F common (c.) $-0,14-0,34, \mathrm{~F}$ water soluble (w.s.) - 0,015-0,24, calcination loss (c. 1.) at $400{ }^{\circ} \mathrm{C}-19,6-19,9$. Phosphogypsum humidity - 20$25 \%, \mathrm{pH}-2,6-3,2$, bulk density $-750-800 \mathrm{~kg} / \mathrm{m}^{3}$, specific surface - 260-290 $\mathrm{m}^{2} / \mathrm{kg}$. Phosphogypsum particles are formed by the dihydrate calcium sulphate crystals of a regular rhomboid. The length of the particles fluctuates from 5 to $300 \mathrm{~mm}$, width - from 1 to $50 \mathrm{~mm}$, thickness - from 0,05 to $0,5 \mathrm{~mm} \mathrm{[3].}$

Semihydrate phosphogypsum $\left(\mathrm{CaSO}_{4} \times 0,5 \mathrm{H}, \mathrm{O}\right)$ forms at $87-95{ }^{\circ} \mathrm{C}$ temperature by reacting the apatite with a sulphuric acid. The chemical composition (calculated for a dry product), \%: $\mathrm{CaO}-35,0-36,4, \mathrm{SO}_{3}-$ $54,4-55,0, \mathrm{R}_{2} \mathrm{O}_{3}-0,5-2,0, \mathrm{P}_{2} \mathrm{O}_{5}$ c. $-1,35-1,50, \mathrm{P}_{2} \mathrm{O}_{5}$ w.s. $-0,35-0,96, \mathrm{~F}_{\text {c. }}-0,30-0,41, \mathrm{~F}_{\text {w.s. }}-0,03-0,05$, calcinations $\operatorname{loss}\left(400^{\circ} \mathrm{C}\right)-5,9-6,32$. Phosphogypsum humidity $-20-25 \%, \mathrm{pH}-2,74-3,3$, bulk density - 1325 $1500 \mathrm{~kg} / \mathrm{m}^{3}$, specific surface $\mathrm{S}_{\mathrm{s} .}$ (measured by the air permeability method) - $100-130 \mathrm{~m}^{2} / \mathrm{kg}$

Gypsum waste from the worn-out gypsum forms from FCJSC "Jiesia". Chemical composition (calculated for a calcinated product), \%: $\mathrm{CaO}-39,20-40,35, \mathrm{SO}_{3}$ $55,8-57,65$, other compounds $-2-4$ (including soluble in water $0,1-1,5)$; calcination loss $\left(400{ }^{\circ} \mathrm{C}\right)-35-38 \%$, bulk density $-800-1100 \mathrm{~kg} / \mathrm{m}^{3}$.

Reagent (activity according to $\mathrm{CaO}-97 \%$ ) and JSC "Kalcitas" industrial [activity according to $(\mathrm{CaO}+$ $\mathrm{MgO})-70$ - $80 \%$ ] lime.

Maleic anhydrite - chemically pure crystallization regulator. Acids and other chemical reagents - chemically pure materials.

\subsection{Methods}

Chemical composition of materials has been determined pursuant to the standards GOST 20851.2-75, LST EN 196-2: 1996, TS 6111045-03-92. Physical and me- chanical investigation of gypsum binding materials has been conducted pursuant to the standard GOST 125-79, GOST 23789-79.

$\mathrm{X}$-ray structural analysis of the materials has been executed by the X-ray diffractometer DRON - 6 with $\mathrm{Cu}$ cathode a radiation.

Calcination loss has been calculated after calcinating the material at $400{ }^{\circ} \mathrm{C}$ temperature.

$\mathrm{pH}$ measurements have been conducted in suspension by a pH-meter $673 \mathrm{M}$ at the ratio of water and solid materials $(\mathrm{V} / \mathrm{K}) 10$.

Neutralization of semihydrate phosphogypsum admixtures has been conducted in 0,002 and $0,05 \mathrm{~m}^{3}$ capacity vessels placed in the thermostat "Grant" SUBl4. The pulp has been mixed by a mechanical mixture "Kika labortechnik" RW 20 n, pH measured by a pH-meter "Sentron" 2001, pH with a sensor electrode pH-meter $673 \mathrm{M}$.

Phosphogypsum has been ground in a ball porcelain mill. The specific surface has been determined by the Blain apparatus applying the air permeability method.

Microscopic analysis has been carried out by the "Combrise" raster electronic microscope.

\section{Analysis results}

The work presents the research results of the application of local waste mentioned above to obtain gypsum binding materials: abstraction ways of gypsum binding materials from the mentioned waste and the properties of the product obtained.

\subsection{Dihydrate phosphogypsum waste}

Reprocessing of dihydrate phosphogypsum into gypsum binding materials is exhaustively investigated and the developed technologies tested by several companies.

In 1987 the refinery of dihydrate phosphogypsum into ( $\beta$-modification) the gypsum plaster was built in Kedainiai adjacent to the chemical factory, designed pursuant to a low-waste technology developed at the Institute of Architecture and Civil Engineering, which was based not on the washing off the acid admixtures with water but their neutralization in lime suspension [3-5] and dehydration of the dried phosphogypsum in the boilers [6]. This production technology of $\beta$-semihydrate gypsum has many advantages: there is no wastewater during production, the process is continuous and the received product has stable properties shown in Table 1.

However, during 1993-94 with the change of the economic situation and the decrease of the gypsum demand, the refinery was closed.

In parallel with the production technology of $\beta$-semihydrate gypsum, the production technology of $\alpha$-semihydrate gypsum has been also developed, it is based on the above-mentioned method of the neutralized dihydrate phosphogypsum in industrial lime suspension 
Table 1. Physical-mechanical properties of gypseous bonding materials produced from dihydrate phosphogypsum

\begin{tabular}{|c|c|c|c|c|c|c|c|}
\hline \multirow[t]{2}{*}{ No } & \multirow[t]{2}{*}{ Gypsum modification } & \multirow{2}{*}{$\begin{array}{c}\mathrm{S}_{\mathrm{s}} \\
\mathrm{m}^{2} / \mathrm{kg}\end{array}$} & \multirow{2}{*}{$\begin{array}{l}\text { Rate } \\
W / G\end{array}$} & \multicolumn{2}{|c|}{$\begin{array}{l}\text { Setting time. } \\
\min \end{array}$} & \multicolumn{2}{|c|}{$\begin{array}{c}\text { Compressive strength. } \\
\mathrm{MPa}\end{array}$} \\
\hline & & & & Initial & Final & After $2 \mathrm{~h}$ & Dry samples \\
\hline 1 & $\beta$-semihydrate gypsum & $500-600$ & $0.55-0.70$ & $10-15$ & $20-25$ & $4-6$ & $9-10$ \\
\hline 2 & $\alpha$-semihydrate gypsum & $300-350$ & $0.36-0.42$ & $10-30$ & $20-45$ & $13-20$ & $40-50$ \\
\hline 3 & $\alpha$-semihydrate gypsum & $200-250$ & $0,38-0,46$ & $15-40$ & $30-60$ & $6-13$ & $35-45$ \\
\hline
\end{tabular}

[3-5] and dehydration under hydrothermal conditions in the autoclave at $130^{\circ} \mathrm{C}$ temperature [7]. The properties of the received product are shown in Table 1.

It was determined by many literature sources and by a long-term research that the properties of gypsum binding materials are closely dependent on the quantity of admixtures in phosphogypsum [3,6, 7, 9]. The smaller the quantity of admixtures, the better properties of the product. Different technologies limit and determine a different quantity required. As a chemical analysis research of dihydrate phosphogypsum present in the phosphogypsum collections - mountains has shown that the quantity of acid admixtures in some places is considerably reduced $\left(\mathrm{P}_{2} \mathrm{O}_{5}\right.$ c. $-0,40-0,50 \%, \mathrm{P}_{2} \mathrm{O}_{5}$ w.s $0,05-0,1 \%$ ), as in a run of time the rain has washed it away. Therefore, production of gypsum binding materials from phosphogypsum waste present in these mountains is very prospective.

\subsection{Semihydrate phosphogypsum waste}

Semihydrate calcium sulphate waste has binding properties, however its application in a natural form is limited due to the existing hazardous admixtures and, therefore, the utilization problem is left unsolved. Such a material is also transported into the waste collections -mountains where, effected by atmospheric humidity, it turns into a dihydrate gypsum stone, the future application of which is very complex. It is rational to use this phosphogypsum before it is hydrated and solidified.

The Department of Silicate Technology has conducted investigation of semihydrate phosphogypsum taken directly from the production line and already dried at $100-120^{\circ} \mathrm{C}$ temperature.

$\mathrm{X}$-ray examination of semihydrate phosphogypsum (Fig l) shows that it consists of $\mathrm{CaSO}_{4} \times 0,5 \mathrm{H}_{2} \mathrm{O}$, and $\mathrm{mi}$ croscopic pictures of phosphogypsum (Fig 2) show that crystals of semihydrate phosphogypsum form dense conglomerates up to the size of $100 \mu \mathrm{m}$.

The research has shown that hydration and physical mechanical properties of this acid semihydrate phosphogypsum depend on acid admixtures soluble in water.

As the data of Table 2 shows, less contaminated phosphogypsum ( $\mathrm{pH}-3,3 \% ; \mathrm{P}_{2} \mathrm{O}_{5 \text { w.s. }}-0,35 \%$ ) tends to hydrate considerably quickly. Calcination loss of phosphogypsum taken from the line is $6,10 \%$, and of the dried one has increased up to $8,64 \%$.

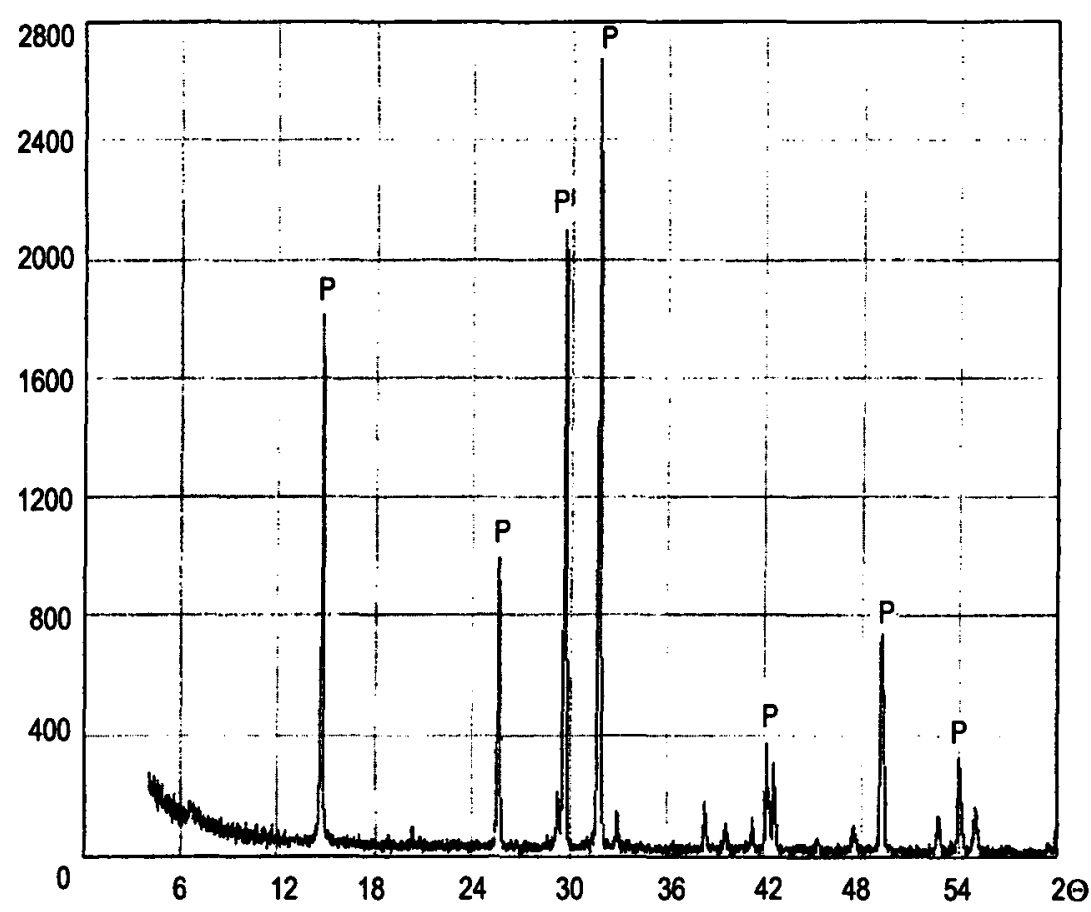

Fig 1. The roentgenogram of semihydrate phosphogypsum ( $\mathrm{P}$ - semihydrate calcium sulphate) 


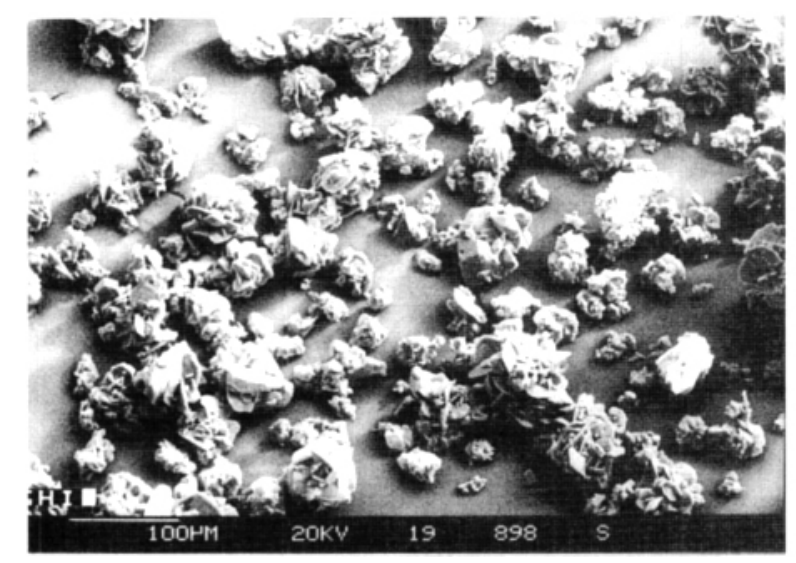

1

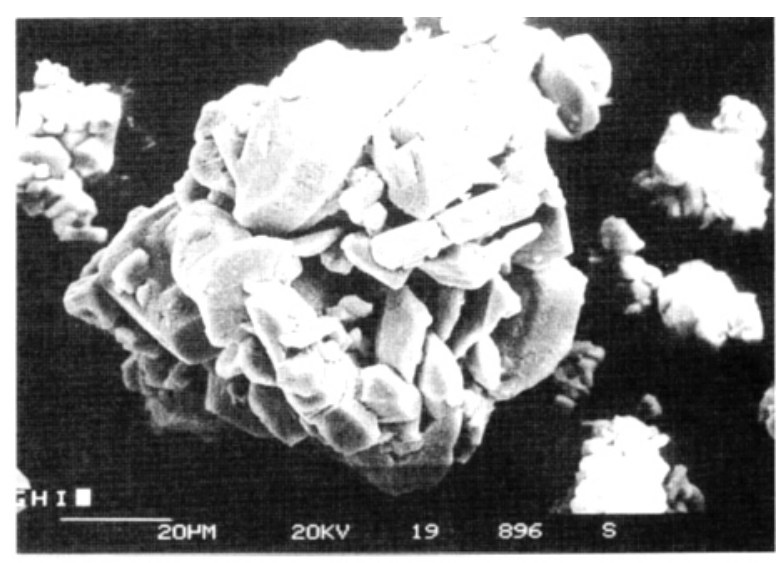

2

Fig 2. The general view of phosphogypsum particles $(1-\times 200,2-\times 2000)$

Table 2. The properties of phosphogypsum

\begin{tabular}{|c|c|c|c|c|c|c|c|c|c|c|c|}
\hline \multirow{2}{*}{ No } & \multirow{2}{*}{$\mathrm{pH}$} & \multirow{2}{*}{$\mathrm{P}_{2} \mathrm{O}_{5}$ w.s' } & \multirow{2}{*}{$\begin{array}{l}\text { Rate } \\
W / G\end{array}$} & \multicolumn{8}{|c|}{ Calcination loss (c.l) after $h$ (hour) and d (days), \% } \\
\hline & & & & $2 \mathrm{~h}$ & $3 h$ & $4 h$ & $1 d$ & $3 \mathrm{~d}$ & $7 \mathrm{~d}$ & $14 d$ & $28 \mathrm{~d}$ \\
\hline 1 & 3,30 & 0,35 & 0,72 & 9,81 & 9,87 & 10,80 & 14,21 & 17,63 & 19,65 & 19,80 & 19,95 \\
\hline 2 & 2,74 & 0,96 & 0,75 & 5,91 & 5,92 & 6,12 & 7,02 & 7,05 & 7,15 & 7,40 & 7,80 \\
\hline
\end{tabular}

Mixed with water, this semihydrate phosphogypsum fully hydrated during 7 days and the samples have reached the strength of $2 \mathrm{MPa}$ during compression; the strength of dry samples during compression was $4,3 \mathrm{MPa}$. More contaminated phosphogypsum ( $\mathrm{pH}-2,74 \%$; $\mathrm{P}_{2} \mathrm{O}_{5 \text { w.s. }}-0,96 \%$ ) has not hydrated and solidified during 28 days. In order to eliminate a negative effect of acid admixtures on the properties of semihydrate phosphogypsum, they must be converted into stable and insoluble compounds. One of the possible ways is our suggested neutralization of acid admixtures in lime suspension at a high $\left(>50^{\circ} \mathrm{C}\right)$ temperature, ie in the temperature, at which no hydration of semihydrate phosphogypsum can be active [9]. Based on this principle is the abstraction way, by which a gypsum binding material or gypsum products complying with valid standard requirements are obtained. The mentioned way has a Lithuanian patent (LT 4699B) [10]. In order to obtain a gypsum binding material or gypsum products, hot phosphogypsum from the conveyor is gradually dosed into the prepared hot reagent lime suspension where it is neutralized pursuant to the set $\mathrm{pH}$ change speed curve up to $\mathrm{pH} 8,5-$ 9,5 . Then the neutralized phosphogypsum suspension (V/K $1-1,5)$ is filtered and phosphogypsum may be applied in two ways:

1. The forms can be filled by hot $\left(>50^{\circ} \mathrm{C}\right)$ neutralized semihydrate phosphogypsum (45-50\% humidity mass) and then gypsum products of different purpose formed.
2. Hot $\left(>50^{\circ} \mathrm{C}\right.$ temperature) neutralized semihydrate phosphogypsum may be dried at $100-120^{\circ} \mathrm{C}$ temperature and ground in a ball mill.

The properties of the product are presented in Table 3. The production way is complex due to the fact that during neutralization and the further processing of semihydrate phosphogypsum the temperature must not fall down below $50{ }^{\circ} \mathrm{C}$ and hydration of $\mathrm{CaSO}_{4} \times 0,5 \mathrm{H}_{2} \mathrm{O}$ must not commence.

The advantage of the indicated production ways are that there is no need to additionally wash phosphogypsum with hot water; therefore there is no contaminated waste water. If semihydrate phosphogypsum is neutralized in lime suspension at the increased temperature $\left(>50{ }^{\circ} \mathrm{C}\right)$ pursuant to the set $\mathrm{pH}$ change curve up $\mathrm{pH} 8,5-9,5$, it is possible to adjust the neutralization process of phosphogypsum contaminated admixtures (to achieve a complete neutralization degree) and the properties of gypsum binding materials. There is no need for thermal processing of phosphogypsum dehydration.

\subsection{Waste from FCJSC “Jiesia" worn-out gypsum forms}

FCJSC "Jiesia" produces gypsum forms from the gypsum G 7-8 made in Ukraine. X-ray, thermographic research as well as the chemical analysis of worn-out gypsum forms show that this is dihydrate calcium sulphate. Without any primary cleaning, this waste is shat- 
Table 3. The strength of samples and neutralized semihydrate phosphogypsum

\begin{tabular}{|l|c|c|c|c|c|c|}
\hline \multirow{2}{*}{$\begin{array}{c}\text { Neutralized phosphogypsum } \\
\text { application ways }\end{array}$} & \multirow{2}{*}{ Rate W/G } & \multicolumn{2}{|c|}{ Setting time, min } & \multicolumn{3}{c|}{ Compressive strength, MPa } \\
\cline { 3 - 7 } & & Initial & Final & 2 h after initial s.t. & $24 \mathrm{~d}$ & Dry samples \\
\hline 1. Formed products & $0,80-1,00$ & 30 & 50 & 4,10 & 6,20 & 18,00 \\
\hline $\begin{array}{l}\text { 2. Dried and and grinded gypsum } \\
\text { binding material, S }\end{array}$ & 0,40 & 65 & 80 & 3,50 & 11,70 & 28,00 \\
\hline
\end{tabular}

tered from slurry and other admixtures by an alligator and grinded in a ball mill. Then the raw material is thermally processed under the atmospheric conditions $\left(\beta-\mathrm{CaSO}_{4} \times 0,5 \mathrm{H}_{2} \mathrm{O}\right.$ is received) and hydrothermal conditions ( $\alpha-\mathrm{CaSO}_{4} \times 0,5 \mathrm{H}_{2} \mathrm{O}$ is received). The parameters of thermal processing have a great impact on the properties of the product received.

As the data in Table 4 show, qualitative gypsum plaster complying with the standard G4 may be obtained from the worn-out gypsum forms after they are shattered. Grinded and thermally processed, $\beta$-semihydrate gypsum is known for the best physical mechanical properties produced at $180^{\circ} \mathrm{C}$ temperature when the duration of isothermal exposure is 4 hours.

Table 4. $\beta$-gypsum properties and the parameters of production

\begin{tabular}{|c|c|c|c|c|}
\hline \multirow{2}{*}{$\begin{array}{c}\text { Rate } \\
\text { W/G }\end{array}$} & \multicolumn{2}{|c|}{$\begin{array}{c}\text { Compressive } \\
\text { strength, } \mathrm{MPa}\end{array}$} & $\begin{array}{c}\text { Temperature of } \\
\text { isothermal } \\
\text { exposure, }{ }^{\circ} \mathrm{C}\end{array}$ & $\begin{array}{c}\text { Isothermal } \\
\text { exposure, } \mathrm{h}\end{array}$ \\
\cline { 2 - 5 } & $2 \mathrm{~h}$ after & $2 \mathrm{~h}$ after & 1 & 8 \\
\hline 0,95 & 1,2 & 4,5 & 150 & 3 \\
\hline 0,86 & 4,1 & 8,7 & 180 & 4 \\
\hline 0,83 & 4,3 & 9,6 & 180 & 6 \\
\hline 0,84 & 4,0 & 9,2 & 180 & 2 \\
\hline 0,82 & 3,9 & 7,6 & 220 & 4 \\
\hline 0.83 & 4,3 & 9,2 & 220 & 6 \\
\hline 0,85 & 4,0 & 8.5 & 220 & 3 \\
\hline 0,83 & 4,1 & 8,2 & 240 & 4 \\
\hline 0,84 & 4,2 & 9,2 & 240 & \\
\hline
\end{tabular}

Production process of $\alpha$-semihydrate gypsum is more complex and sensitive. Not only parameters of autoclave process (pressure, temperature, duration of thermal exposure) have a great effect on the product properties but also the admixtures, particularly those soluble in the water (of soda, fluid glass). The most effective way to eliminate them is to wash them off till $\mathrm{pH}$ of the solution reaches the value close to 7 . The optimum quantity of $\alpha$-semihydrate gypsum crystallization regulator maleic anhydrate $(0,1 \%$ of the binding material) is determined. Temperature and duration of the hydrothermal processing are also very significant to gypsum dehydration.

Table 5 presents the research results of the dependence of $\alpha$-gypsum samples strength during compression on temperature and duration of the isothermal exposure.
The product microscopic analysis has determined that large $\alpha$-semihydrate gypsum crystals form already after 4 hours of isothermal exposure at $125^{\circ} \mathrm{C}$ temperature, resulting in the sample strength of $9,0-10 \mathrm{MPa}$ during compression after 2 hours of solidifying; and in the strength of dry samples of up to $20 \mathrm{MPa}$.

Table 5. $\alpha$-gypsum properties and the parameters of production

\begin{tabular}{|c|c|c|c|c|}
\hline \multirow{2}{*}{$\begin{array}{l}\text { Rate } \\
\text { W/G }\end{array}$} & \multicolumn{2}{|c|}{$\begin{array}{l}\text { Compressive } \\
\text { strength, MPa }\end{array}$} & \multirow{2}{*}{$\begin{array}{c}\text { Temperature of } \\
\text { isothermal } \\
\text { exposure, }{ }^{\circ} \mathrm{C}\end{array}$} & \multirow{2}{*}{$\begin{array}{r}\text { Isothermal } \\
\text { exposure, } \mathrm{h}\end{array}$} \\
\hline & $2 \mathrm{~h}$ after & Dry & & \\
\hline 0,51 & 4.5 & 13,7 & $120-130$ & 1,5 \\
\hline 0,50 & 8,7 & 20.5 & $120-130$ & 4 \\
\hline 0,49 & 9,5 & 22.0 & $120-130$ & 5 \\
\hline 0,46 & 15,0 & 25,0 & $120-130$ & 9 \\
\hline 0,53 & 10,5 & 22,0 & $115-120$ & 4 \\
\hline 0.51 & 10.8 & 19,8 & $125-135$ & 4 \\
\hline 0.56 & 6,5 & 15,6 & $130-140$ & 4 \\
\hline
\end{tabular}

\section{Conclusions}

The long-term research on forming gypsum waste at the Lithuanian industrial enterprises has shown that after an additional processing it is suitable for production of gypsum binding materials and products.

1. It was determined that it is possible to produce $\alpha$ and $\beta$-semihydrate gypsum from JSC "Lifosa" dihydrate phosphogypsum $\left(\mathrm{CaSO}_{4} \times 2 \mathrm{H}_{2} \mathrm{O}\right)$ abstracted till 1997. Their properties depend on the soluble acid admixtures present in the waste. At present this waste is disposed in mountains and, effected by atmospheric precipitation, is washed off the mentioned admixtures, therefore it becomes a qualitative raw material for gypsum.

2. It is possible to receive a gypsum binding material from semihydrate phosphogypsum currently forming at JSC "Lifosa", after its acid admixtures are neutralized in the lime suspension at $>50^{\circ} \mathrm{C}$ temperature without an additional thermal processing. The strength of such material during compression after $2 \mathrm{~h}$ of solidifying reaches $3,5 \mathrm{MPa}$, and of dry samples - 28,0 MPa. Such production would be ex- 
tremely cost-effective, as it may be organized directly in the same building, by taking the raw material from a band transporter and building three additional neutralization, drying and grinding technological units.

3. $\beta$-semihydrate gypsum can be obtained from the worn-out gypsum forms of FCJSC "Jiesia". The strength of such gypsum during compression after $2 \mathrm{~h}$ of solidifying reaches $4,0 \mathrm{MPa}$, and of dry samples - 10,0 MPa. $\alpha$-semihydrate gypsum can also be obtained, the strength of which during compression correspondingly after $2 \mathrm{~h}$ of solidifying is 9$10 \mathrm{MPa}$, and of dry samples - up to $20 \mathrm{MPa}$.

\section{References}

1. Eventshik C. D., Novikov A. A. Phosphogypsum and its application (Фосфогипс и его использование). Moscow, 1990, p. 81-83, 89-103 (in Russian).

2. Talipov S. N., Atakusijew T. A., Negmatow S. S. Production of b-semihydrate sulfate from phosphogypsum using thermal processing technology. In: Proc. of the 14th intern. conference of building materials. Held on September 20-23. The materials of conference reports. Weimar, 2000, Vol 2, p. 429-434 (in German).

3. Kaziliūnas A., Leškevičienè V., Vektaris B., Valančius Z. Neutralization research of phosphogypsum admixtures.
Chemical technology, No 3(9). Kaunas, 1998, p. 38-45 (in Lithuanian).

4. Patent 1224287. 1985 (in Russian).

5. Patent 1375605. 1987 (in Russian).

6. Bačauskiene $M$. Phosphogypsum dehydration and its thermal processing technology for obtaining $\beta$-semihydrate calcium sulphate (Дегидратация фосфогипса и технология его тепловой обработки для получения $\beta$-полугидрата сульфата кальция). Summary of dissertation of technical sciences. Kaunas, 1983 (in Russian)

7. Valančius Z. Technological background of $\alpha$-semihydrate gypsum production from phosphogypsum ( $\alpha$-pushidračio gipso gamybos iš fosfogipso technologiniai pagrindai). Summary of dissertation of technical sciences. Kaunas, 1992. 17 p. (in Lithuanian).

8. Kaminskas A., Kaminskas R. Research on semihydrate calcium sulphate $\left(\mathrm{E}-\mathrm{CaSO}_{4} \times 0,5 \mathrm{H}_{2} \mathrm{O}\right)$ obtained by extraction from apatite. In: Proc. of the 14 th intern. conference of building materials. Held on September 20-23. The materials of conference reports. Weimar, 2000 , Vol 2, p. 451 459 (in German)

9. Leškevičienė V., Nizevičienè D., Valančius Z. Neutralization of semihydrate phosphogypsum acid admixtures and property analysis. Chemical technology, No 1. Kaunas, 2000, p. 10-16 (in Lithuanian).

10. Patent LT 4699 B. 2000 (in Lithuanian) 